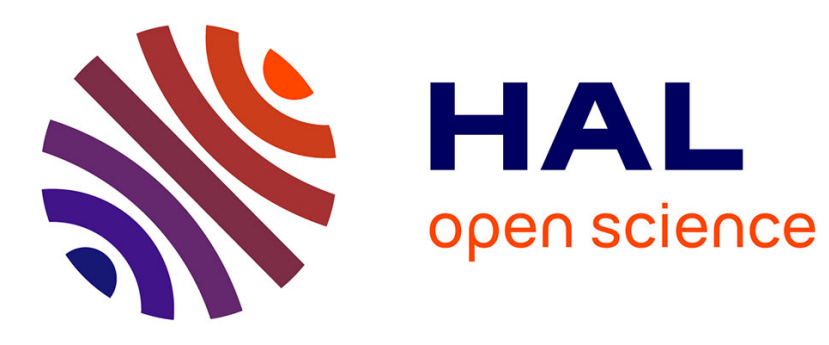

\title{
Integrated drought responses of black poplar: how important is phenotypic plasticity?
}

Marie Garavillon Tournayre, Aurelie Gousset, Florian Gautier, Pierrick

Benoit, Pierre Conchon, Romain Souchal, David Lopez, Gilles Petel, J. S.

Venisse, Catherine Bastien, et al.

\section{To cite this version:}

Marie Garavillon Tournayre, Aurelie Gousset, Florian Gautier, Pierrick Benoit, Pierre Conchon, et al.. Integrated drought responses of black poplar: how important is phenotypic plasticity?. Physiologia Plantarum, 2018, 163 (1), pp.30-44. 10.1111/ppl.12646 . hal-01830337

\section{HAL Id: hal-01830337 https://hal.science/hal-01830337}

Submitted on 26 May 2020

HAL is a multi-disciplinary open access archive for the deposit and dissemination of scientific research documents, whether they are published or not. The documents may come from teaching and research institutions in France or abroad, or from public or private research centers.
L'archive ouverte pluridisciplinaire HAL, est destinée au dépôt et à la diffusion de documents scientifiques de niveau recherche, publiés ou non, émanant des établissements d'enseignement et de recherche français ou étrangers, des laboratoires publics ou privés. 


\title{
Integrated drought responses of black poplar: how important is phenotypic plasticity?
}

\author{
Marie Garavillon-Tournayre ${ }^{a}$, Aurélie Gousset-Dupont ${ }^{a}$, Florian Gautier ${ }^{b}$, Pierrick Benoit ${ }^{a}$, \\ Pierre Conchon ${ }^{a}$, Romain Souchal ${ }^{a}$, David Lopez ${ }^{a}$, Gilles Petela ${ }^{a}$, Jean-Stéphane Venisse ${ }^{a}$, \\ Catherine Bastien ${ }^{b}$, Philippe Labe ${ }^{a, \dagger}$ and Boris Fumanal ${ }^{a,{ }^{*}, \dagger}$ (i) \\ aUniversité Clermont Auvergne, INRA, PIAF, F-63000 Clermont-Ferrand, France \\ bINRA Centre Val de Loire, UAGPF, F-45075 Orléans, France
}

\section{Correspondence \\ *Corresponding author, \\ e-mail: boris.fumanal@uca.fr}

Received 20 March 2017;

revised 24 July 2017

doi:10.1111/ppl.12646
Climate change is expected to increase drought frequency and intensity which will threaten plant growth and survival. In such fluctuating environments, perennial plants respond with hydraulic and biomass adjustments, resulting in either tolerant or avoidant strategies. Plants' response to stress relies on their phenotypic plasticity. The goal of this study was to explore physiology of young Populus nigra in the context of a time-limited and progressive water deficit in regard to their growth and stress response strategies. Fourteen French 1-year-old black poplar genotypes, geographically contrasted, were subjected to withholding water during 8 days until severe water stress. Water fluxes (i.e. leaf water potentials and stomatal conductance) were analyzed together with growth (i.e. radial and longitudinal branch growth, leaf senescence and leaf production). Phenotypic plasticity was calculated for each trait and response strategies to drought were deciphered for each genotype. Black poplar genotypes permanently were dealing with a continuum of adjusted water fluxes and growth between two extreme strategies, tolerance and avoidance. Branch growth, leaf number and leaf hydraulic potential traits had contrasted plasticities, allowing genotype characterization. The most tolerant genotype to water deficit, which maintained growth, had the lowest global phenotypic plasticity. Conversely, the most sensitive and avoidant genotype ceased growth until the season's end, had the highest plasticity level. All the remaining black poplar genotypes were close to avoidance with average levels of traits plasticity. These results underpinned the role of plasticity in black poplar response to drought and calls for its wider use into research on plants' responses to stress.

\footnotetext{
Abbreviations - $\Psi_{\mathrm{pd}}$, predawn leaf water potential; $\Psi_{\mathrm{md}}$, midday leaf water potential; $\theta_{\text {max }}$ maximum annual average temperature; $\theta_{\min }$, minimum annual average temperature; $D$, main branch diameter gain; $g_{s}$, stomatal conductance; $H$, tree height before experiment; L, new branch length gain; Light, mean number of sunny days per years; $N$, number of new leaves per branch; $p_{-}$, plasticity of; PCA, principal component analysis; SLA, specific leaf area; Rain, mean number of rainy days per years; RDPI, Relative Distance Plasticity Index; T, total leaf number variation.
}

$\dagger$ These authors contributed equally to this work. 


\section{Introduction}

Ongoing global climate change is expected to increase both the intensity and the frequency of future extreme climatic events (Beniston et al. 2007, Burkett et al. 2014). In temperate countries, drought episodes will be part of the more intense climatic changes (van Mantgem et al. 2009, Anderegg et al. 2013, Cisneros et al. 2014), and have already been held responsible for some observed forest die-offs (Bréda et al. 2006).

Trees physiological responses to water deficit result in hydraulic and carbon cycle adjustments, which have already been well described (Parker 1956, Bréda et al. 2006). Stomatal closure initiates the phenotypic responses to edaphic water deficit (Tardieu and Simonneau 1998, Marron et al. 2002, Bogeat-Triboulot et al. 2007). Stomatal aperture regulation acts as a safety barrier that reduces water loss by leaf transpiration (Stalfelt 1955, Barrs 1971, Brodribb and Holbrook 2003, Araújo et al. 2011). The evaporative demand of the plant persists despite water constraints, leading to a progressive tension increase in the water column (Tyree and Sperry 1988, Sellin 1999, Sack and Holbrook 2006). If water deficit is prolonged, cavitation events can occur in the vascular system (Milburn 1966, Nardini et al. 2001, Brodribb and Holbrook 2003, Cochard et al. 2007). Nevertheless, xylem functionality could be recovered after rewatering (McCully 1999, Brodribb and Cochard 2009). These hydraulic variations are evenly supported by morphological and physiological changes at the whole plant scale, such as a decrease of cellular elongation and surface of new leaves growing during drought (Battaglia et al. 1998, Pedrol et al. 2000, Marron et al. 2002, logna et al. 2013, Bizet et al. 2014). Even with non-critical levels of dehydration, carbon assimilation is strongly reduced (Thomas and Eamus 1999, Lambers et al. 2008, Hamanishi et al. 2012). As a consequence, biomass production falls dramatically (Bray 1997, Caruso et al. 2002, Monclus et al. 2006, Bonhomme et al. 2008), and ultimately ceases. In the final stages of severe drought response, combined hydraulic failure and carbon depletion can result in plant death (McDowell et al. 2008, Sala et al. 2010, Sevanto et al. 2014). Plants response strategies depicted in different species are complex, owing to strong regulation of physiological traits that enables plants to tolerate water stress, and avoid instant death.

Poplar is widely used as a tree model (Bradshaw et al. 2000, Taylor 2002) to study physiological responses to water deficit in plants. Populus nigra grows in a wide range of geographical climates (Cagelli and Lefèvre 1995), most of which are in riparian stands and wetlands (Rameau et al. 1989, Isebrands and Richardson
2014). Black poplar is a pioneer species characterized by a strong colonization power during juvenile status when growth rate supported by high water consumption is the highest. This meso-hygrophilous species, used in breeding programs, is known to be particularly vulnerable to water deficit despite its rusticity (Bréda et al. 2006). Significant natural variations in phenotypic responses have been shown among European genotypes subjected to moderate drought suggesting their adaption to local climatic events (Viger et al. 2016). These results were supported by an integrated study revealing that genetic and morphological characteristics of 13 European P. nigra populations should depend on adaptive differentiation and historic local events (DeWoody et al. 2015). In addition, French genotypes exhibiting the greatest genetic admixture (DeWoody et al. 2015) showed heterogeneous drought responses (Viger et al. 2016). Regarding to these results, conclusions should be tried on larger set of French black poplar genotypes responding to drought to explore their phenotypic and genetic particularities, and estimate the degree of the response variability. Two water deficit response strategies have been identified in poplar species and hybrids regarding to water fluxes and biomass production parameters: tolerance and avoidance (Marron et al. 2003, Monclus et al. 2006, Giovannelli et al. 2007). The tolerant strategy is defined by the capacity of a perennial plant to sustain growth and biomass production by maintained stomatal aperture or a loosely regulated one (Passioura 2002), while limiting dehydration by leaf osmotic adjustments (Gebre et al. 1994, Marron et al. 2002, Hanin et al. 2011, Barchet et al. 2013, Martorell et al. 2014). The avoidant strategy is based on limiting water loss through quick stomatal closure and/or leaf abscission (Couso and Fernandez 2012). Similar strategies have been identified in other poplar species, with a broad range of variations in physiological trait regulation (Brignolas et al. 2000); notably, stomatal sensitivity (Hamanishi et al. 2012), leaf abscission, leaf production (Marron et al. 2002) and general plant growth (Giovannelli et al. 2007). However, there is a continuum of responses depicting these two strategies according to individuals in a population, or even in the same individual according the environment. To cope with environmental changes, perennial plants have three options: local adaptation (Kawecki and Ebert 2004), new colonization (Sax et al. 2007) or phenotypic plasticity. Phenotypic plasticity is defined as the capacity of a genotype to produce different phenotypes in response to environmental conditions (Bradshaw 1965, Sultan 2000, Nicotra et al. 2010). A part of the total phenotypic plasticity can be evaluated using many indices (Valladares et al. 2006) focused on plant traits. The level of plasticity depends on species (logna et al. 2013, McKown et al. 
2014), genotypes (Bizet et al. 2014), the considered plant trait (Couso and Fernandez 2012) and growth conditions.

Levels of phenotypic plasticity can become adaptive and inheritable especially when expressed by plants under recurrent environmental modifications. Adaptive plasticity can benefit survival, growth and reproduction (Van Kleunen and Fischer 2005, Chevin and Lande 2009, Ghalambor et al. 2015), as suggested for adaptive receptor sensitivity to environmental cues (Nicotra et al. 2010). Energy consumption required for the modification of a stable trait must be proportional to the intensity of environmental stress (Valladares and Niinemets 2008) to avoid ineffective extreme phenotypic plasticity (DeWitt et al. 1998, Steinger et al. 2003). The environmental predictability, i.e. the match between environmental cues and the level of plant phenotypic plasticity, appears crucial for the efficiency of plant phenotypic adjustments (Moran 1992, Reed et al. 2010). In an environment which will undergo drastic changes, as expected in the future, plant plasticity should play a major role in plant interactions, selection pressure, competition for resources and plant persistence (Parmesan and Hanley 2015).

The aim of this study was to characterize the main early physiological responses of young black poplar during a time-limited progressive drought. The followed goals were (1) to evaluate the extent of phenotypic plasticity involvement in drought responses, and (2) to decipher relationships between phenotypic plasticity and response strategies to water deficit. Fourteen black poplar genotypes, from contrasted geographical origins in France, were subjected to water withholding until they reached a severe water deficit, as measured by predawn leaf water potential. Physiological and growth traits were monitored during the water treatment. Genotype strategies integrating trait plasticities were studied using a multivariate analysis.

\section{Materials and methods}

\section{Plant material and experimental design}

Fourteen European P. nigra genotypes were sampled by INRA UR 0588 AGPF (Orléans, France) in natural riparian populations (Villar and Forestier 2009) from different French river basins characterized by different climatic conditions (Table 1). They were kept in annually coppiced mother-stocks at the ONF nursery of Guéméné-Penfao $\left(47.62^{\circ} \mathrm{N}, 1.84^{\circ} \mathrm{E}\right)$. Eight cuttings per genotype $(1 \mathrm{~cm}$ collar diameters, $30 \mathrm{~cm}$ height) were planted in $10 \mathrm{I}$ pots in spring 2012. Pot substrate was composed of one-third black peat and two-thirds local Limagne topsoil, added with $20 \mathrm{~g}$ of Osmocot
Pro fertilizer (17:11:10 N, P, K, 2 MgO). Pots were set up in the common garden at Clermont Auvergne University, Clermont-Ferrand $\left(45.76^{\circ} \mathrm{N}, 3.12^{\circ} \mathrm{E}\right)$ using a complete randomized block design. Trees were spaced $1 \mathrm{~m}$ apart and surrounded by additional randomized clones from the different genotypes tested in order to minimize edge effects. Pots were watered automatically twice a day ( $0.5 \mathrm{I}$ in the morning and afternoon) until the onset of water deficit. The experiment ran from June 11, 2013 to June 18, 2013 on 107 one-year-old black poplars $(401 \pm 10$ leaves, $16 \pm 1 \mathrm{~mm}$ of stem diameter). Trees height before experiment start was not different between clones within genotypes $(P=0.127)$. However, two genotypes among the 14 had significantly different heights $(P=0.002)$ from $75 \pm 6 \mathrm{~cm}$ for ERS-12 to $125 \pm 7 \mathrm{~cm}$ for SPM-40. Four clones per genotype were subjected to water deficit (except two for 77-308 and ERS-12 genotypes) by withholding water until all genotypes exceeded at least a predawn leaf water potential of $-2 \mathrm{MPa}$, corresponding to 8-day treatment and severe water deficit (Marron et al. 2003). Pots were weighed daily to check water deficit (mean water loss of $1.6 \% \pm 0.1$ per day and per pot; Fig. S1, Supporting Information). Four control trees per genotype were well-watered (only three ERS-12 trees). The soil of droughted trees was covered with plastic bags sealed with silicone at the tree collar to prevent rehydration by rain and morning dew. At the end of the experiment, the trees were re-watered and monitored until the season's end (October 19, 2013).

\section{Water movements}

Predawn and midday leaf water potential $\left(\Psi_{\mathrm{pd}}\right.$ and $\Psi_{\text {md }}$, expressed in $\mathrm{MPa}$ ) were measured on rank-four leaves from the top with a Scholander pressure chamber (Model 600; PMS Instrument Company, Albany, OR) every 2 days. $\Psi_{\text {pd }}$ was measured from $04 \mathrm{~h} 30 \mathrm{~min}$ to $05 \mathrm{~h}$ $15 \mathrm{~min}$, i.e. before sunrise, (1) to control steady state of water status along the soil-plant-atmosphere continuum for control trees and (2) to reach at least $\Psi_{\text {pd }}=-2 \mathrm{MPa}$ for the droughted trees. $\Psi_{\text {md }}$ was measured between $13 \mathrm{~h} 00$ and $13 \mathrm{~h} \mathrm{45}$, i.e. at peak transpiration.

Stomatal conductance $\left(\mathrm{g}_{\mathrm{s}}, \mathrm{mmol} \mathrm{m}^{-2} \mathrm{~s}^{-1}\right.$ ) was measured daily between $13 \mathrm{~h} 00$ and $13 \mathrm{~h} 45$ on rank-four leaves using an SC-1 Leaf Porometer (Decagon Devices, Pullman, WA).

\section{Plant growth and development}

Poplar architecture features sylleptic and proleptic branching (Hallé et al. 1978, Ceulemans et al. 1990, Wu and Hinckley 2001). Tree organs were annotated 
Table 1. Annual averages of climatic parameters between 1981 and 2010 defining the native environmental conditions of the 14 black poplar genotypes studied. a A minimum of $1 \mathrm{~mm}$ of rainfall and $120 \mathrm{~W} \mathrm{~m}{ }^{-2}$ of sunshine per day was taken into account for number of days counting. ${ }^{\mathrm{b}}$ The hottest month was July for each sampling origin.

\begin{tabular}{|c|c|c|c|c|c|c|c|c|c|c|}
\hline \multirow[b]{2}{*}{ Genotype } & \multirow[b]{2}{*}{ Latitude } & \multirow[b]{2}{*}{ Longitude } & \multirow[b]{2}{*}{ Sampling origin } & \multicolumn{2}{|c|}{ Average temperature $\left({ }^{\circ} \mathrm{C}\right)$} & \multicolumn{3}{|c|}{ Cumulative rainfall } & \multicolumn{2}{|c|}{ Total sunshine } \\
\hline & & & & Minimal & Maximum & $\begin{array}{l}\text { Height } \\
\text { (mm) }\end{array}$ & $\begin{array}{l}\text { Number } \\
\text { of days }\end{array}$ & $\begin{array}{l}\text { Height }(\mathrm{mm}), \text { for the } \\
\text { hottest month }\end{array}$ & Duration (h) & $\begin{array}{c}\text { Number of } \\
\text { days }^{a}\end{array}$ \\
\hline STR-10 & 48.37 & 7.49 & Strasbourg & 6.6 & 15.3 & 665.0 & 114.9 & 72.7 & 1692.7 & 59.8 \\
\hline STR-16 & 48.37 & 7.49 & Strasbourg & 6.6 & 15.3 & 665.0 & 114.9 & 72.7 & 1692.7 & 59.8 \\
\hline ERS-05 & 48.25 & 7.43 & Erstein & 6.1 & 15.7 & 607.3 & 103.9 & 66.8 & 1799.0 & 62.2 \\
\hline ERS-10 & 48.25 & 7.43 & Erstein & 6.1 & 15.7 & 607.3 & 103.9 & 66.8 & 1799.0 & 62.2 \\
\hline ERS-12 & 48.25 & 7.43 & Erstein & 6.1 & 15.7 & 607.3 & 103.9 & 66.8 & 1799.0 & 62.2 \\
\hline RHN-35 & 48.16 & 7.41 & Rhinau & 6.1 & 15.7 & 607.3 & 103.9 & 66.8 & 1799.0 & 62.2 \\
\hline RHN-38 & 48.16 & 7.41 & Rhinau & 6.1 & 15.7 & 607.3 & 103.9 & 66.8 & 1799.0 & 62.2 \\
\hline SPM-12 & 47.51 & 1.48 & Saint-Pryvé Saint-Mesmin & 5.8 & 16.7 & 702.3 & 113.8 & 59.9 & 1743.6 & 60.3 \\
\hline SPM-28 & 47.51 & 1.48 & Saint-Pryvé-Saint-Mesmin & 5.8 & 16.7 & 702.3 & 113.8 & 59.9 & 1743.6 & 60.3 \\
\hline SPM-40 & 47.51 & 1.48 & Saint-Pryvé Saint-Mesmin & 5.8 & 16.7 & 702.3 & 113.8 & 59.9 & 1743.6 & 60.3 \\
\hline ALL-29 & 46.24 & 3.19 & Val d'Allier & 6.0 & 16.7 & 779.5 & 116.7 & 71.6 & 1861.7 & 68.7 \\
\hline $77-308$ & 45.54 & 5.12 & Meximieux & 8.1 & 16.9 & 831.9 & 104.1 & 77.7 & 2001.9 & 81.1 \\
\hline $72-501$ & 45.35 & 5.36 & Saint-Genix sur Guiers & 6.3 & 16.2 & 934.3 & 106.4 & 86.6 & 2065.9 & 88.1 \\
\hline $\mathrm{BDG}$ & 44.04 & 0.54 & Garonne & 8.4 & 18.5 & 712.2 & 107.1 & 51.3 & 1982.4 & 75.7 \\
\hline
\end{tabular}

to take into account these two branching processes: the stem, the longest past year sylleptic shoot (named main branch) and one proleptic shoot developed on the main branch (named new branch). Measurements of radial growth ( $D$, at $5 \mathrm{~cm}$ from the collar or terminal bud scar) and longitudinal growth (L) were performed during the water deficit period.

Total leaf number per tree were counted before and after the water deficit then divided by leaf number at the beginning of the experiment (T, \%). Apical meristems were marked before the experiment in order to count the number of new leaves produced during the stress on the new branch $(\mathrm{N})$. Three rank-four leaves per tree grown during the water deficit were sampled (except one stressed leaf for 77-308 and BDG, and none for stressed ERS-12 trees owing to lack of leaves) to evaluate the specific leaf area (SLA). Then for each fresh leaf, leaf area $\left(A, \mathrm{~mm}^{2}\right)$ was measured using IMAGEJ software (version 1.48; Schneider et al. 2012) and leaf dry mass $\left(\mathrm{M}, \mathrm{mg}\right.$ ) was obtained after 4 days drying at $60^{\circ} \mathrm{C}$. Mean $\mathrm{SLA}\left(\mathrm{mm}^{-2} \mathrm{mg}^{-1}\right)$ per tree was calculated as $\mathrm{SLA}=\mathrm{A} / \mathrm{M}$.

\section{Statistical analysis}

The effects of water deficit and genotype were analyzed over time on stomatal conductance, predawn and midday leaf water potentials of trees using mixed effects linear model and contrast analysis using post hoc Tukey's test.

Physiological and growth traits measured at the maximum water deficit (day 8) were analyzed using a multivariate principal component analysis (PCA) on standardized values. Shapiro-Wilk's test was used to check Gaussian distribution for all variables. Climatic variables $\left(\theta_{\min }\right.$, minimum annual average temperature; $\theta_{\max }$, maximum annual average temperature; Rain, mean number of rainy days per year; Light, mean number of sunny days per year) describing the original environment of each genotype and their height $(\mathrm{H}$, trees height before experiment) were added to the PCA as supplementary variables. Eigenvalues were calculated for the first five dimensions. The contributions of each variable $\left(\mathrm{C}_{\mathrm{var}}\right)$ and each individual $\left(\mathrm{C}_{\text {ind }}\right)$ to these dimensions were compared with theoretical equivalent contribution $\left(C_{t h}\right)$, defined as: $C_{\mathrm{th}}=1 /$ variable number. Variables and individuals with a significant contribution $\left(\mathrm{C}_{\mathrm{var}}>\mathrm{C}_{\mathrm{th}}\right.$ or $\mathrm{C}_{\text {ind }}>\mathrm{C}_{\mathrm{th}}$ ) to the dimensions and a quality of representation (range of explicative dispersion, $\cos ^{2}$ ) in the plane above 0.60 were retained to help describe genotype behaviors during the water deficit. V-test results (Lebart et al. 1995) singled out genotypes belonging to the first two dimensions. These screening criteria allowed choosing the most informative traits, which were then compared among treatment and between genotypes using two-way ANOVA and post hoc Tukey's test.

The plasticity of the most informative physiological and growth trait (D, L, N, T, $\Psi_{\mathrm{pd}}$ and $\left.\Psi_{\mathrm{md}}\right)$ was calculated using the Relative Distance Plasticity Index (RDPI; Valladares et al. 2006) varying from 0 to 1 (respectively low and high plasticity) for each variable and genotype as: $\operatorname{RDPI}=\Sigma\left(\left|\mathrm{x}_{\mathrm{ij}}-\mathrm{x}_{\mathrm{i}^{\prime} j^{\prime}}\right| /\left(\mathrm{x}_{\mathrm{ij}}+\mathrm{x}_{\mathrm{i}^{\prime} \mathrm{j}^{\prime}}\right)\right) / \mathrm{n}$, where $\mathrm{x}_{\mathrm{ij}}$ defines the value of a variable in treatment $i$ (well-watered or droughted) for trees $j,\left|x_{i j}-x_{i^{\prime} j^{\prime}}\right|$ is the absolute difference obtained between all pairs of trees from two different treatments, and $\mathrm{n}$ is the total number of pairs. The 
corresponding variables were named after their physiological counterpart and prefixed $p_{\text {_. }}$. The relationships of trait plasticity indexes were analyzed using a PCA. Kruskal and Wallis test has been performed on each RDPI trait to estimate the genotype effect (Table S3).

Statistical analyses were performed using $\mathrm{R}$ software version 3.2.1 with $\alpha=0.05$. FACTOMINER (Le et al. 2008) and FACTOEXRA R packages were used to perform a PCA analysis and visualized results.

\section{Results}

\section{Evolution of physiological plant status during progressive water deficit}

Stomatal conductance $\left(g_{\mathrm{s}}\right)$, predawn $\left(\Psi_{\mathrm{pd}}\right)$ and midday $\left(\Psi_{\mathrm{md}}\right)$ leaf water potentials were significantly different $(P<0.001)$ between well-watered and droughted trees over time (Fig. 1). No significant genotype effect has been detected over time on $\Psi_{\mathrm{pd}}(P=0.150)$ and $\Psi_{\mathrm{md}}(P=0.142)$. The $g_{\mathrm{s}}$ value of trees under water deficit significantly fell throughout the time course compared with well-watered ones, from $171 \pm 19$ at day 2 to $32 \pm 3 \mathrm{mmol} \mathrm{H}_{2} \mathrm{O} \mathrm{m}^{-2} \mathrm{~s}^{-1}$ at day 3 , and then stabilized until the end of the experiment (Fig. 1A). A notable variability in $g_{s}$ was also observed on well-watered trees during the experiment (from 146 131 to $512 \pm 49 \mathrm{mmol} \mathrm{m}^{-2} \mathrm{~s}^{-1}$ ). Predawn and midday leaf water potentials of well-watered poplars remained stable during the progressive water treatment, respectively $\Psi_{\mathrm{pd}}=0 \mathrm{MPa}$ and $\Psi_{\mathrm{md}}=-1 \mathrm{MPa}$ (Fig. 1B, C). The expected decrease of $\Psi_{\mathrm{pd}}$ and $\Psi_{\mathrm{md}}$ were significant respectively after four $(P<0.001)$ and eight $(P<0.001)$ days of water deficit, reaching $-2.8 \pm 0.1 \mathrm{MPa}$ for $\Psi_{\mathrm{pd}}$ and $-2.6 \pm 0.2 \mathrm{MPa}$ for $\Psi_{\mathrm{md}}$ at day 8 .

\section{Whole trait relationships}

The global response of trees to severe water deficit (day 8) was studied by PCA of the eight measured physiological and growth traits along with five supplementary quantitative variables. On the main plane representing $62 \%$ of global variance (Fig. 2A), individuals projection revealed the effect of water deficit on individual clustering, and split individuals into two groups along the first PCA dimension (correlation $=0.83, P<0.001$ ). The underlying structure of variance was summarized by few traits (Fig. 2B): total leaf number variation (T) and predawn leaf water potential $\left(\Psi_{\mathrm{pd}}\right)$. They were respectively positively and negatively correlated with the first dimension. Midday leaf water potential $\left(\Psi_{\mathrm{md}}\right)$, radial (D) and longitudinal (L) growths and number of new leaves per new branch $(\mathrm{N})$ contribute to the variance of the first axis in a lesser extent. SLA and stomatal conductance $\left(g_{\mathrm{s}}\right)$ did
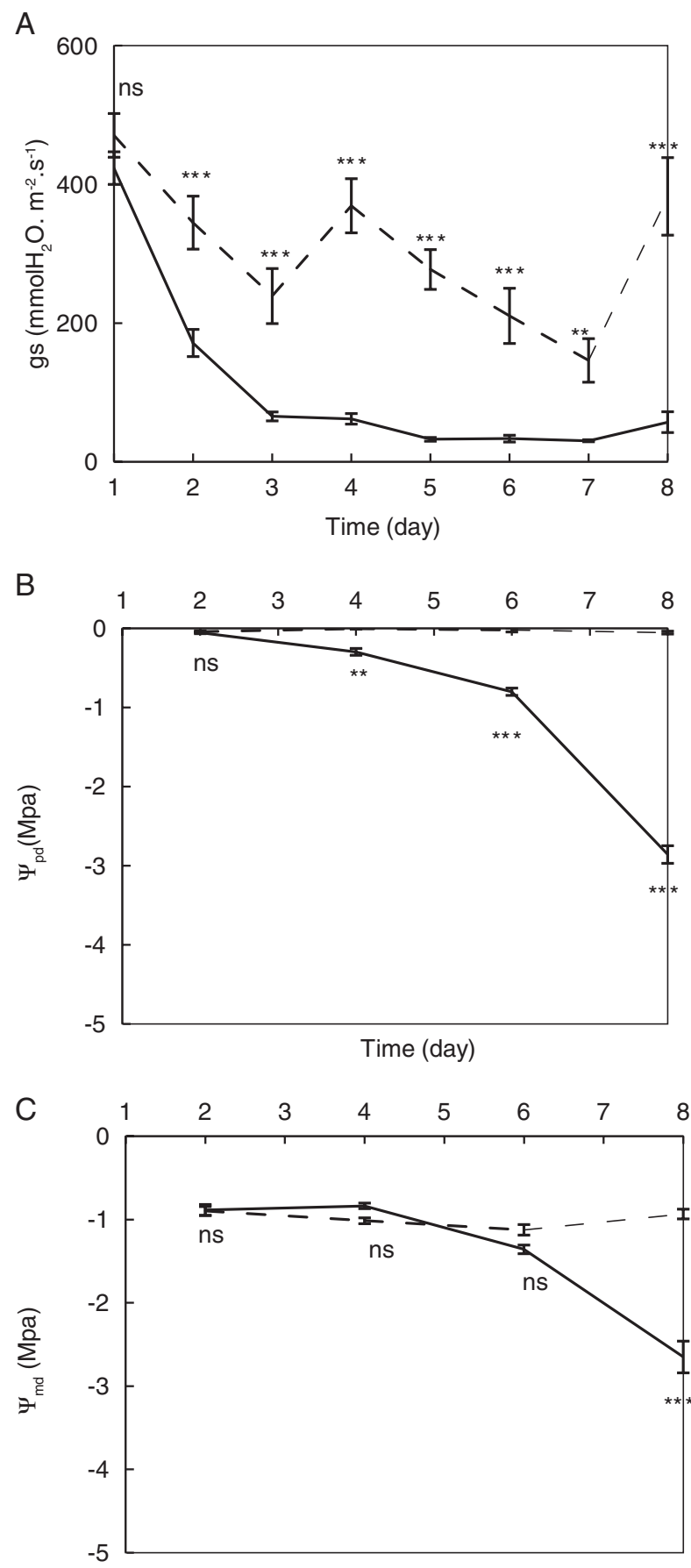

Fig. 1. Mean ( $\pm \mathrm{SE}$ ) stomatal conductance $(\mathrm{A})$ and predawn $(\mathrm{B})$ and midday (C) leaf water potential of black poplars in well-watered (dotted line) and water deficit (solid line) conditions. Results of mixed effects linear model and post hoc Tukey's test are indicated $\left({ }^{*} 0.01<P<0.05\right.$; $* * 0.01<P<0.001 ; * * * P<0.001 ;$ ns, non-significant). 
A

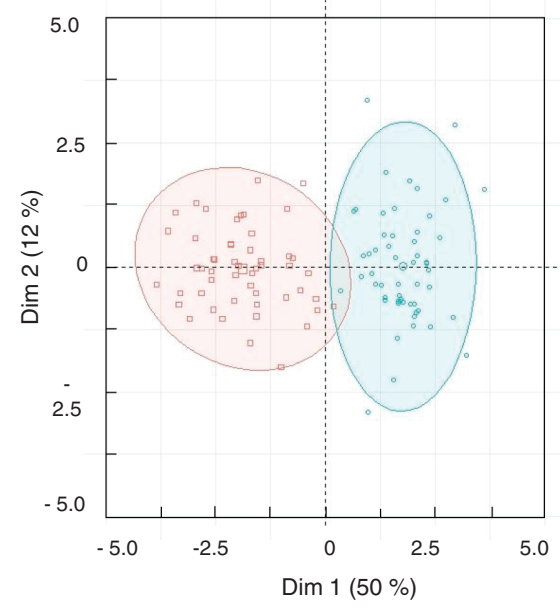

B

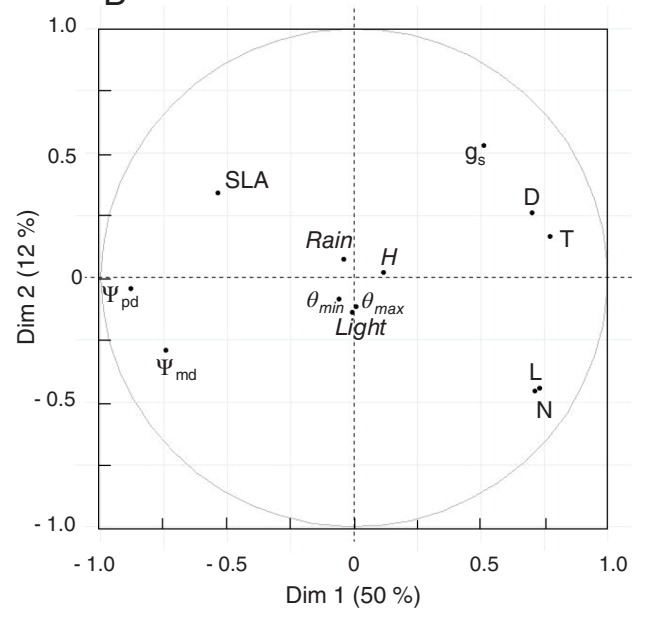

Fig. 2. PCA on physiological and growth traits of 14 black poplar tree genotypes at the maximal water deficit (day 8 ). Individual trees projected on the first two PCA dimensions, representing $62 \%$ of global variance. (A) Droughted (red dots) and well-watered (blue dots) trees with their $95 \%$ confidence ellipsese. (B) Eight physiological and growth variables (with correlation circles) projected on the first two PCA dimensions, including five climatic and tree traits supplementary variables (italic). $g_{\mathrm{s}}=$ stomatal conductance; $\Psi_{\mathrm{pd}}=$ predawn leaf water potential; $\Psi_{\text {md }}=$ midday leaf water potential; $\mathrm{D}=$ main branch diameter gain; $\mathrm{L}=$ new branch length gain; $\mathrm{T}=$ total leaf number variation; $\mathrm{N}=$ number of new leaves per branch; SLA $=$ specific leaf area; $\theta_{\min }=$ minimum annual average temperature; $\theta_{\max }=$ maximum annual average temperature; $R$ ain $=$ mean number of rainy days per years; $L$ ight $=$ mean number of sunny days per years; $H=$ tree height before experiment.

Table 2. Test of genotype and treatment effect on physiological and growth traits of 14 black poplar genotypes at the maximal water deficit (day 8 ) using two-way anova. * Significant difference for $P<0.05$.

\begin{tabular}{|c|c|c|c|}
\hline \multirow[b]{2}{*}{ Description of physiological traits } & \multicolumn{3}{|c|}{ Two-way Anova $P$-values significance } \\
\hline & Genotype & Treatment & Genotype $\times$ Treatment \\
\hline \multicolumn{4}{|l|}{ Water movement traits } \\
\hline Stomatal conductance $\left(g_{s}, \mathrm{mmol} \mathrm{m}^{-2} \mathrm{~s}^{-1}\right)$ & 0.175 & $<0.001 *$ & 0.458 \\
\hline Predawn leaf water potential $\left(\Psi_{\mathrm{pd}}, \mathrm{MPa}\right)$ & 0.096 & $<0.001^{*}$ & 0.369 \\
\hline Midday leaf water potential $\left(\Psi_{\mathrm{md}}, \mathrm{MPa}\right)$ & 0.602 & $<0.001 *$ & 0.726 \\
\hline \multicolumn{4}{|l|}{ Growth and development traits } \\
\hline \multicolumn{4}{|l|}{ Branch } \\
\hline Main branch diameter gain $(D, m m)$ & $0.030 *$ & $<0.001 *$ & 0.294 \\
\hline New branch length gain $(\mathrm{L}, \mathrm{cm})$ & $0.009 *$ & $<0.001 *$ & $0.039 *$ \\
\hline \multicolumn{4}{|l|}{ Leaf } \\
\hline Total leaf number variation (T, \%) & 0.135 & $<0.001 *$ & $0.018^{*}$ \\
\hline Number of new leaves per branch (N) & 0.092 & $<0.001 *$ & 0.556 \\
\hline
\end{tabular}

not bring significant contribution to the variance on the main plane. Projecting genotypes onto the PCA main plane revealed weak correlation with the second dimension (correlation $=0.11, P>0.05$ ). Climatic parameters describing the original environment of genotypes and the height of trees, analyzed as supplementary variables, did not yield any significant contribution to global variance on the main PCA plane.

\section{Water movements}

Trees lost on average $7.7 \pm 0.3 \%$ of water content $(P<0.001)$ when water deficit was maximal at day 8
(Fig. S1). There were no significant differences between genotypes $(P>0.05)$.

Water deficit induced a steady decrease of $\Psi_{\mathrm{pd}}$ in droughted trees until day $8(P<0.001$; Table 2$)$ reaching different rates according to genotype: from $-1.9 \pm 0.2 \mathrm{MPa}$ for SPM-12 to $-4.1 \pm 0.3 \mathrm{MPa}$ for ERS-12 (Fig. 3). At day 8, $\Psi_{\mathrm{md}}$ of well-watered trees ranged from $-0.7 \pm 0.1 \mathrm{MPa}$ to $-1.4 \pm 0.2 \mathrm{MPa}$ between genotypes. Among droughted trees, $\Psi_{\mathrm{md}}$ fell $(P<0.001$; Table 2$)$ from $-1.8 \pm 0.2 \mathrm{MPa}$ for $\mathrm{SPM}-12$ to $-3.7 \pm 0.3 \mathrm{MPa}$ for ERS-12 genotype (Fig. 3), without any significant differences among genotypes $(P>0.05)$. 

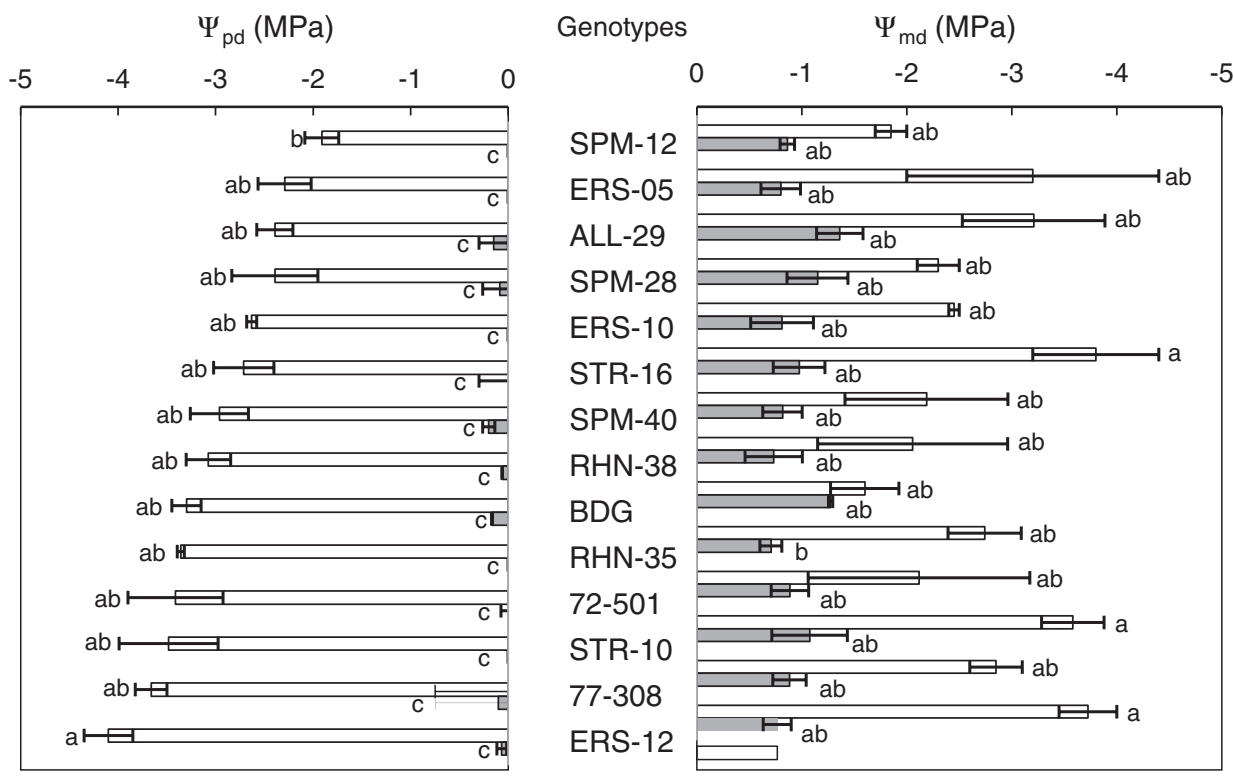

Fig. 3. Mean ( \pm SE) predawn ( $\left.\Psi_{\mathrm{pd}}\right)$ and midday $\left(\Psi_{\mathrm{md}}\right)$ leaf water potential measured on 14 well-watered (gray bars) and droughted (white bars) black poplar genotypes at the maximal water deficit (day 8). Results of two-way ANova and post hoc HSD Tukey's test are indicated by letters. Same letters indicate no differences between groups.

\section{Plant growth and development}

Total leaf number variation (T) increased by $53 \pm 16 \%$ for control trees on average (from $414 \pm 14$ to $516 \pm 20$ leaves; Fig. 4A). It peaked on average at $35 \% \pm 5$ among droughted trees (from $388 \pm 14$ to $229 \pm 20$ leaves; $P<0.001$; Table 2) reaching $90 \%$ for genotypes 77-308 and ERS-12 (Fig. 4A) because of leaf fall following drought stress. Genotype and treatment effects interacted significantly for this trait $(P=0.018$; Table 2).

Globally, number of new leaves $(\mathrm{N})$ was significantly reduced by water deficit $(P<0.001$; Table 2$)$, although this trend was not always significant at the genotype level. However, $\mathrm{N}$ of two droughted genotypes, BDG and STR-16 ( $P<0.01$; Fig. 4B), decreased by twofold compared with control trees. Similarly, a significant increase of SLA in water deficit treatment was observed $(P<0.001 ;$ Table 2; Fig. S2) but no difference was noted between genotypes.

The main effect of water deficit was clearly detected on longitudinal (L) and radial (D) growth $(P<0.001$; Table 2). However, only genotype $x$ treatment interaction was significantly detected for $\mathrm{L}(P=0.039$; Table 2$)$. When examined at the genotype level, decrease in $\mathrm{L}$ under water deficit was significant for BDG, RHN-35, SPM-28 and SPM-40 $(P<0.05$; Table S1). The main effect of water deficit on $D$ decrease was the most marked in STR-10 and RHN-35 genotypes $(P<0.05$; Table S1).

\section{Phenotypic plasticity}

Plasticity of physiological and growth traits was derived as RDPI for each genotype, and analyzed using PCA (Fig. 5). Variance was mostly explained by the first three PCA dimensions $(26,22$ and $21 \%$, respectively). The first two dimensions represented $48 \%$ of global variance (Fig. 5A). p_L and p_ $\Psi_{p d}$ contributed weakly to the variance of the first dimension (29 and 27\%; Table S2). The variance represented on the second dimension was mainly because of $p_{-} T$ contributing to $47 \%$, followed by $p_{-} \Psi_{m d}$, contributing to $18 \%$. The genotype factor explained 55, 54 and $30 \%$ of the variance of the first three dimensions respectively (Fig. 5C, D). ERS-05 was significantly and positively correlated to the first dimension $(P=0.01)$ although SPM40 $(P=0.01)$ and BDG $(P=0.002)$ were negatively correlated (Fig. 5 C). ERS-12 and $\mathrm{RHN}-35$ were positively correlated with the second dimension $(0.03<P<0.04)$ and anticorrelated with SPM-12, SPM-40 and ALL-29 $(P=0.02)$. BDG was the only genotype significantly correlated with the third dimension $(P=0.01)$. $p_{-} \Psi_{\text {pd }}, p_{-} T$ and $p_{-} D$ were associated with the genotypes significantly well represented on the first three dimensions. The significant genotype effect was confirmed on these three traits $(P<0.05$; Table S3).

PCA highlighted four traits for which plasticity was genotype-specific: $p_{-} \Psi_{p d}$, $p_{-} D, \quad p_{-} L$ and $p_{-} T$. $p_{-} \Psi_{\text {pd }}$ showed the highest RDPI (Table 3) among all the genotypes (RDPI $>0.9$ ). p_D ranged between $0.18 \pm 0.05(72-501)$ and $0.57 \pm 0.02(77-308)$, p_L 


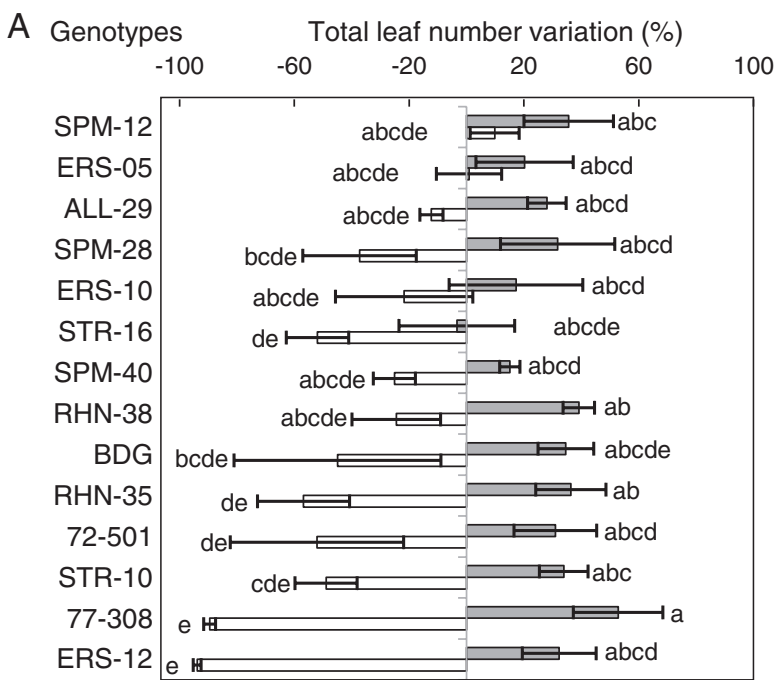

B Genotypes Number of new leaves per branch

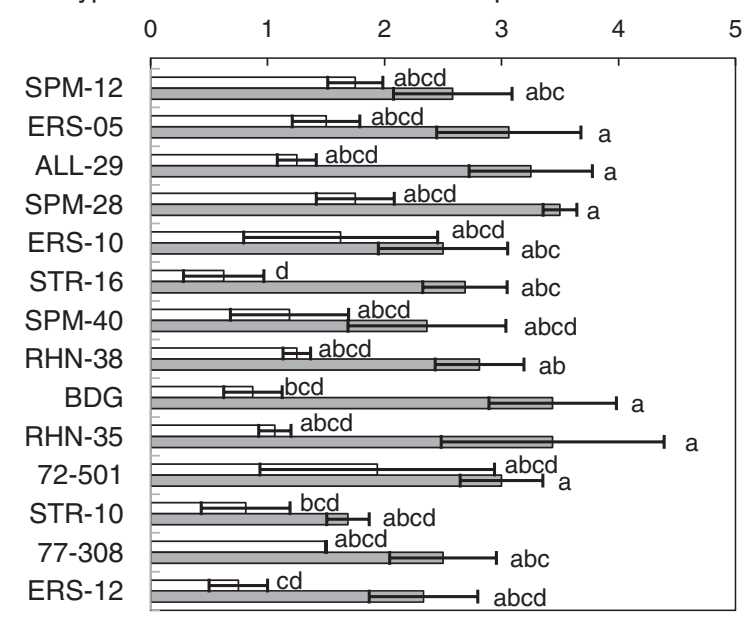

Fig. 4. Mean ( $\pm \mathrm{SE}$ ) total leaf number variation $(A)$ and number of new leaves per branch (B) of 14 well-watered (gray bars) and droughted (white bars) black poplar genotypes at the maximal water deficit (day 8). Results of two-way ANova and post hoc HSD Tukey's test are indicated by letters. Same letters indicate no differences between groups.

from $0.27 \pm 0.03$ (ERS-05) and $0.67 \pm 0.19$ (SPM-28), and $p_{-} T$ from $0.13 \pm 0.02$ (SPM-12) to $0.91 \pm 0.01$ (ERS-12). P_ $\Psi_{\mathrm{md}}$ was lower for BDG $(0.15 \pm 0.08)$ than for the other genotypes (from $0.36 \pm 0.02$ for SPM-12 to $0.66 \pm 0.01$ for ERS-12). p_N ranged between $0.20 \pm 0.04$ (SPM-12) and $0.65 \pm 0.13$ (STR-16).

\section{Discussion}

Black poplars belong to riparian species with high evaporative demand during juvenile stage (Bazzaz 1979). Surprisingly, this pioneer species could also colonize dry soil habitats (Rameau et al. 1989). One way to explore its acclimatization capacity face to future climate disturbances is to study its response trait plasticity. In this study, 14 contrasting native black poplar genotypes were exposed to progressive severe water deficit to explore the diversity of responses of this species. Our main goal was to evaluate the importance of plasticity in plant response strategy to water deficit.

\section{Black poplars were severely stressed after an 8-day water deficit}

Considering global variance of each physiological trait measured (Fig. 2), an 8-day water deficit was enough to induce a strong response for all the 14 black poplar genotypes. They were characterized by well-known changes in physiological traits, confirming their reached severe water deficit status as reported for many species. We observed a rapid decrease in stomatal conductance (Tardieu and Simonneau 1998, Marron et al. 2002, Marron et al. 2003, Aasamaa et al. 2004, Bogeat-Triboulot et al. 2007, Almeida-Rodriguez et al. 2010), a progressive increase of tension in the water column (Shackel et al. 1997, Fu et al. 2006, Almeida-Rodriguez et al. 2010, Cocozza et al. 2010, Barchetet al. 2013), leaf abscission (Marron et al. 2002, Viger et al. 2016), and a reduction of radial and longitudinal growth (Morabito et al. 2006, Giovannelli et al. 2007). A relation between the decrease of water fluxes $\left(g_{\mathrm{s}}, \Psi_{\mathrm{pd}}, \Psi_{\mathrm{md}} ;\right.$ Fig. 2B) and growth traits $(\mathrm{T}, \mathrm{N})$ was observed in all the genotypes, as previously described by Lambs et al. (2006), Chamaillard et al. (2011) and Viger et al. (2016) on other black poplar genotypes.

\section{Black poplar genotypes exhibited a wide range of response to water deficit}

At the genotype level, variability of response to water deficit was detectable. ERS-12, 77-308, and STR-10 regulated mostly water movements $\left(\Psi_{\mathrm{pd}}, \Psi_{\mathrm{md}}\right)$, while STR-16 and BDG were mainly characterized by a decrease of growth $(T, N)$. Little changes occurred in SPM-12, which sustained the highest $\Psi_{\text {pd }}(-1.9 \mathrm{MPa})$, still producing new leaves and keeping existing leaves during water deficit. On the other end of the response gradient, ERS-12, 77-308, and STR-10 experienced $\Psi_{\mathrm{pd}}$ around $-4 \mathrm{MPa}$ and stopped growing. To ensure that all the genotypes were able to continue growth as normal following, we re-watered them and measured their growth restart before the end of the growing season (Table S1). At that point, one genotype (ERS-12) failed to recover its growth, possibly because of vascular system and/or photosynthesis pathway damages (Fichot et al. 2015, Jajic et al. 2015, Chen et al. 2016). The following year, we checked the growth of all the plants. All the genotypes, even those experiencing severe stress with extreme $\Psi_{\text {pd }}$ were able 
A
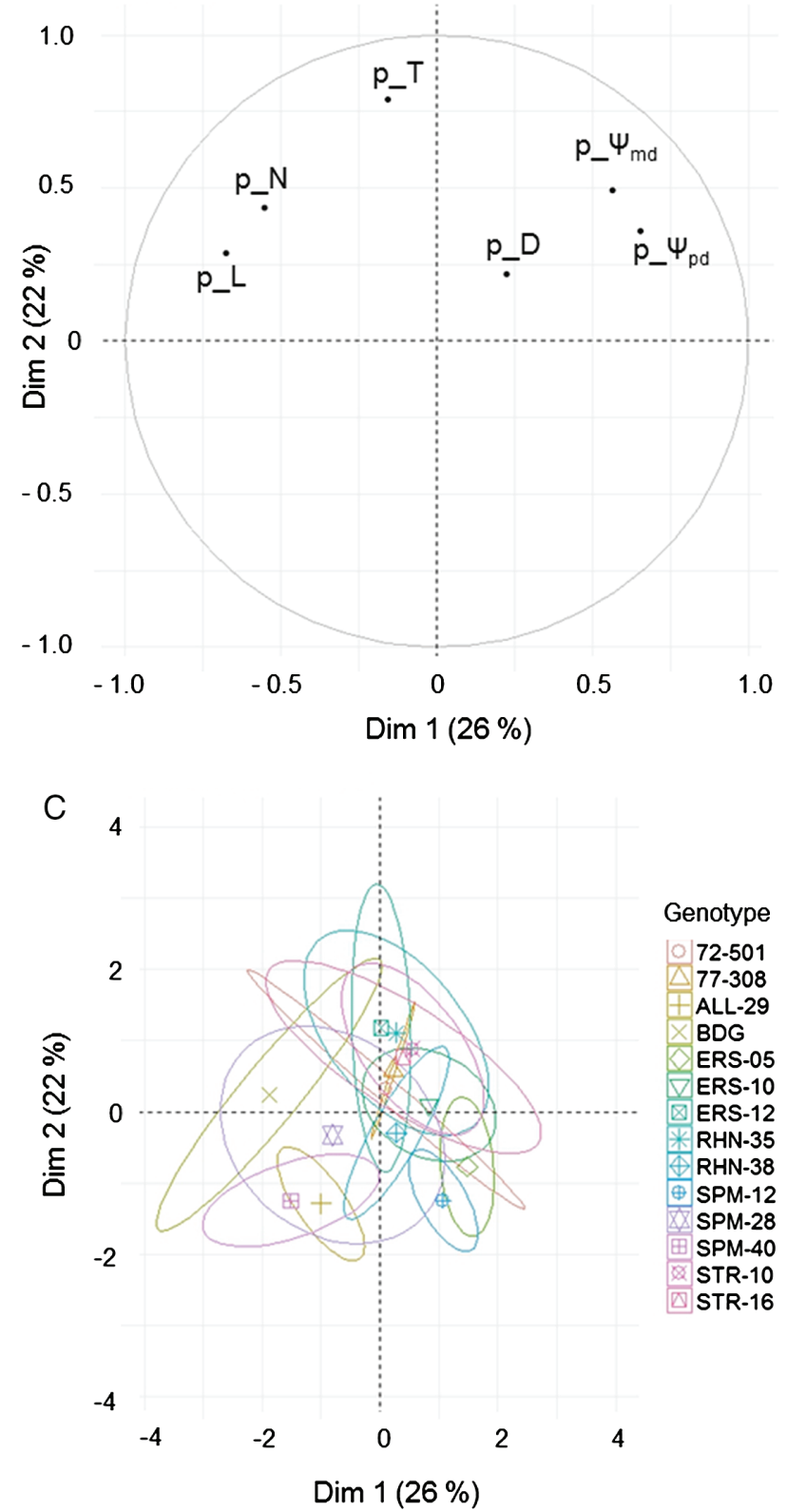

Genotype

이 $72-501$

$\triangle 77-308$

ALL-29

BDG

ERS-05

$\nabla$ ERS-10

$\triangle$ ERS-12

* RHN-35

(4) RHN-38

SPM-12

SPM-28

SPM-40

STR-10

STR-16
B

1.0

0.5

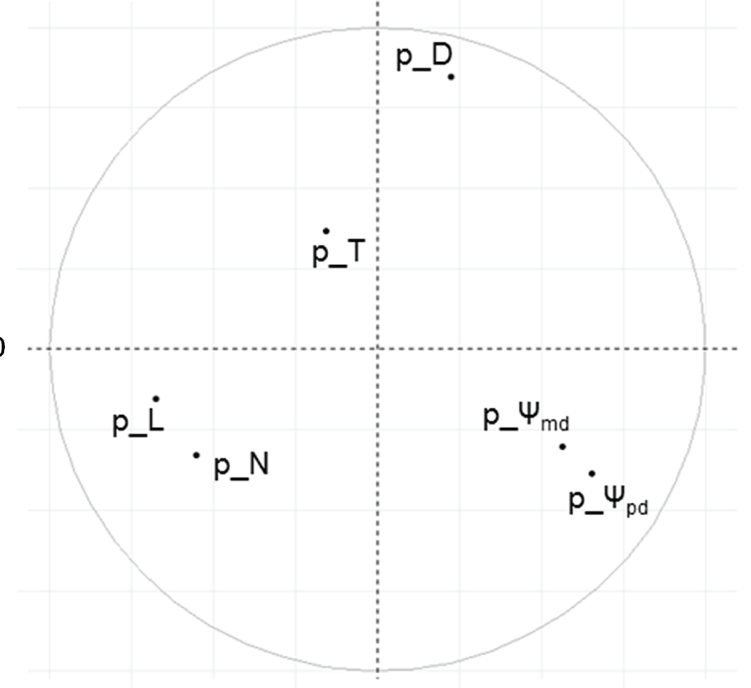

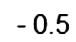

$-0.5$

0

0.5

1.0

Dim 1 (26\%)

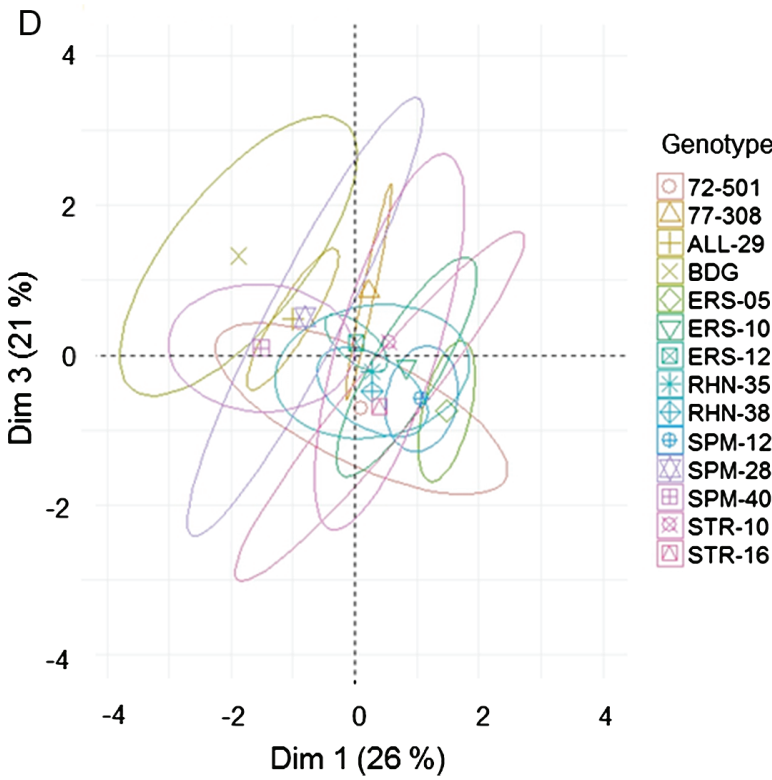

Fig. 5. PCA of phenotypic plasticity as a RDPI calculated for six traits on 14 black poplar genotypes at the maximal water deficit (day 8). Data structuring is detected on $(A, C)$ the first plane (dimension 1 and 2 ) and $(B, D)$ the second plane (dimensions 1 and 3). (A, B) Correlation circles of traits RDPI on the first three dimensions. (C, D) Trees are identified according to genotype factor on the two planes with $95 \%$ confidence ellipses drawn around each genotype barycenter. $p_{-}=$plasticity of; $\Psi_{\mathrm{pd}}=$ predawn leaf water potential; $\Psi_{\mathrm{md}}=$ midday leaf water potential; $\mathrm{D}=$ main branch diameter gain; $L=$ new branch length gain; $T=$ total leaf number variation; $N=$ number of new leaves per branch.

to recover from this severe water deficit (including ERS-12 plants). Similar observations have been made on severely droughted poplar species (Brignolas et al. 2000, Marron et al. 2003, Almeida-Rodriguez et al. 2010, Cocozza et al. 2010, Barchet et al. 2013).

Genotypes modulated evapotranspiration similarly during water deficit: it is thus surprising that SPM-12 has been able to grow in such conditions. Black poplars mostly responded by leaf fall during water deficit except for two genotypes (SPM-12 and ERS-05). In black poplars (Regier et al. 2009, Cocozza et al. 2010) and several other poplar species (Pelah et al. 1997, Marron et al. 2002, Bogeat-Triboulot et al. 2007, Barchet et al. 2013, Cao et al. 2013, Hamanishi et al. 2015), authors have 
Table 3. Mean ( \pm SE) RDPI of 14 black poplar genotypes at the maximal water deficit (day 8) for six physiological traits.

\begin{tabular}{|c|c|c|c|c|c|c|}
\hline Genotypes & $p_{-} \Psi_{p d}$ & p_D & p_L & $p_{-} T$ & $p_{-} \Psi_{m d}$ & $\mathrm{P}_{-} \mathrm{N}$ \\
\hline SPM-12 & $1.00 \pm 0.01$ & $0.27 \pm 0.05$ & $0.41 \pm 0.04$ & $0.13 \pm 0.02$ & $0.36 \pm 0.02$ & $0.20 \pm 0.04$ \\
\hline ERS-05 & $1.00 \pm 0.01$ & $0.30 \pm 0.05$ & $0.27 \pm 0.03$ & $0.14 \pm 0.03$ & $0.57 \pm 0.09$ & $0.33 \pm 0.07$ \\
\hline ALL-29 & $0.89 \pm 0.01$ & $0.38 \pm 0.04$ & $0.48 \pm 0.08$ & $0.19 \pm 0.02$ & $0.39 \pm 0.07$ & $0.43 \pm 0.05$ \\
\hline SPM-28 & $0.93 \pm 0.01$ & $0.42 \pm 0.20$ & $0.67 \pm 0.19$ & $0.38 \pm 0.15$ & $0.36 \pm 0.03$ & $0.34 \pm 0.07$ \\
\hline ERS-10 & $1.00 \pm 0.01$ & $0.44 \pm 0.06$ & $0.47 \pm 0.07$ & $0.30 \pm 0.12$ & $0.53 \pm 0.01$ & $0.39 \pm 0.07$ \\
\hline STR-16 & $1.00 \pm 0.01$ & $0.41 \pm 0.15$ & $0.41 \pm 0.13$ & $0.35 \pm 0.06$ & $0.60 \pm 0.03$ & $0.65 \pm 0.13$ \\
\hline SPM-40 & $0.89 \pm 0.01$ & $0.28 \pm 0.01$ & $0.60 \pm 0.03$ & $0.22 \pm 0.04$ & $0.39 \pm 0.14$ & $0.43 \pm 0.12$ \\
\hline RHN-38 & $0.96 \pm 0.01$ & $0.25 \pm 0.01$ & $0.45 \pm 0.05$ & $0.31 \pm 0.08$ & $0.52 \pm 0.09$ & $0.38 \pm 0.04$ \\
\hline $\mathrm{BDG}$ & $0.91 \pm 0.01$ & $0.50 \pm 0.13$ & $0.57 \pm 0.05$ & $0.66 \pm 0.14$ & $0.15 \pm 0.08$ & $0.59 \pm 0.09$ \\
\hline RHN-35 & $1.00 \pm 0.01$ & $0.41 \pm 0.02$ & $0.55 \pm 0.16$ & $0.54 \pm 0.10$ & $0.59 \pm 0.04$ & $0.49 \pm 0.04$ \\
\hline $72-501$ & $1.00 \pm 0.01$ & $0.18 \pm 0.05$ & $0.47 \pm 0.19$ & $0.55 \pm 0.16$ & $0.48 \pm 0.07$ & $0.40 \pm 0.09$ \\
\hline STR-10 & $1.00 \pm 0.01$ & $0.52 \pm 0.17$ & $0.56 \pm 0.04$ & $0.46 \pm 0.08$ & $0.56 \pm 0.02$ & $0.43 \pm 0.18$ \\
\hline $77-308$ & $0.95 \pm 0.01$ & $0.57 \pm 0.02$ & $0.49 \pm 0.01$ & $0.87 \pm 0.02$ & $0.53 \pm 0.02$ & $0.23 \pm 0.01$ \\
\hline ERS-12 & $0.97 \pm 0.01$ & $0.45 \pm 0.05$ & $0.59 \pm 0.24$ & $0.91 \pm 0.01$ & $0.66 \pm 0.01$ & $0.50 \pm 0.09$ \\
\hline
\end{tabular}

reported that species without leaf fall under drought may favor solute availability and sustain cellular homeostasis. The question remains unanswered for SPM-12, in which growth was maintained during water deficit.

SPM-12 strategy face to water deficit conditions was considered as 'tolerant' according to previous findings on poplar species (Marron et al. 2002, Monclus et al. 2006, Cocozza et al. 2010). By contrast, the strategy of ERS-12 was closer to the description of 'avoidant', as described for $P$. simonii $\times$ P. balsamifera (Almeida-Rodriguez et al. 2010). Based on this definition, the 12 other black poplar genotypes could also be regarded as 'avoidant'. Although poplar is known to be meso-hygrophilous to slightly hygrophilous in regularly flooded environments, it can sustain growth under occasional short drought periods, in accordance with some reports of French black poplar colonizing dry substrates (Rameau et al. 1989).

\section{Phenotypic plasticity related to drought strategy was genotype-specific}

Phenotypic plasticity (Fig. 5) was evaluated for traits related to water movements $\left(p_{-} \Psi_{p d}, p_{-} \Psi_{m d}\right)$ and growth (p_L, p_D, p_T, p_N). Multivariate analysis retained $p_{-} \Psi_{\text {pd }}, p_{-} D, p_{-} L$ and $p_{-} T$ as genotype-specific, characterizing the diversity of plasticity responses of black poplar genotypes. Growth traits show medium plasticity levels as previously observed for black poplar genotypes (Guet et al. 2015), Populus $\times$ euramericana (Bizet et al. 2014), Pinus pinaster (Alía et al. 1997, Lamy et al. 2014), Pinus halepensis (Baquedano et al. 2008) or Quercus coccifera. Discriminatory power of plasticities among genotypes was higher for the growth traits $p_{-} D_{\text {, }}$ $p_{-} T, p_{-} L$ than for $p_{-} \Psi_{p d}$, owing to large differences in plasticity levels between genotypes (e.g. $0.13<$ RDPI
$<0.9$ for $p_{-}$T). The highest plastic trait to water deficit was $p_{-} \Psi_{\text {pd }}$ with RDPI from 0.89 to 1.0 (Table 3).

Black poplar genotypes developed different plasticity patterns to withstand a short-term severe water deficit (Fig. 5): ERS-05 was characterized by a high $p_{-} \Psi_{\text {pd }}$ and a low P_L/p_D contrary to BDG and SPM-40. Two genotypes (ERS-12 and RHN-35) were associated with high P_T $_{-}$in contrast with SPM-12, SPM-40 and ALL-29. In addition, the least plastic black poplar genotype (SPM-12, Table 3) was tolerant to severe water deficit, whereas the most plastic genotype (ERS-12) was avoidant. Earlier reports, of low plasticities of fitness-related traits (i.e. total biomass and tillering, Couso and Fernandez 2012), $\Psi_{50}$ (Fichot et al. 2010), water fluxes, gas exchange and antioxidant traits (Baquedano et al. 2008) associated with drought tolerance, support this result. Differences in plasticity among genotypes could be partially explained by different selection pressure on traits occurring in their native environments (Valladares et al. 2007). Plants adapted to a predictable environment and under low selection pressure, offer low plasticity in response to non-predictable water deficit because they are unable to adjust rapidly their physiological traits (Henry and Aarssen 1997, Valladares et al. 2005, Ghalambor et al. 2007, Willis et al. 2008, Reed et al. 2010). A low plasticity can be efficient to sustain primary metabolism (Valladares et al. 2000). However, these plants take a risk: low plastic genotypes are usually close to their hydraulic safety margin and incur hydraulic failure (McDowell et al. 2008). Conversely, species responding to water deficit by high plasticity could allocate resources to non-essential phenotypic modifications, which could be detrimental to their fitness (Alpert and Simms 2002, Steinger et al. 2003). Parmesan and Hanley (2015) pointed out the complex impact of plasticity on plant performances under climate 
change, which also depends on non-climatic constraints (i.e. interactions between species). Transplantation experiments suggested that their plasticity level depend on species (Willis et al. 2008, Early and Sax 2014, Hargreaves et al. 2014, Dalmaris et al. 2015) and was not necessarily conditioned by climatic factors (Early and Sax 2014, Bradley et al. 2015).

In our experiment, medium-to-high plasticity was concomitant to avoidance for 13 black poplar genotypes out of the 14 tested. Unexpectedly, the more plastic genotype was the more avoidant whereas the least plastic one was drought tolerant. Our results suggested that an avoidant strategy combined with a certain amount of response trait plasticity might reduce the plant performances for resources allocation and threatened poplar persistence in occasionally droughted environments. A better understanding of the molecular basis of the phenotypic plasticity could be approached by studying the relationships between phenotypic plasticity and transcriptional responses of poplars subjected to drought, as recently shown by some authors (i.e. Cohen et al. 2010, Hamanishi et al. 2010, Hamanishi et al. 2015, Viger et al. 2016).

\section{Author contributions}

B. F. designed the study; F. G., B. F., P. B., P. C. and R. S. performed the ecophysiological measurements; M. G. T. and B. F. performed the statistical analysis; P. L., A. G., C. B., J. S. V., D. L. and G. P. contributed to the interpretation of results; M. G. T., B. F., A. G. and P. L. wrote the manuscript, with the contribution of all authors.

Acknowledgements - The authors are indebted to the French national programme of conservation of genetic resources of Populus nigra, and especially Marc Villar (INRA Orléans, coordinator) and Olivier Forestier (ONF Guémené Penfao, in charge of vegetative reproduction and stoolbed management) for providing cuttings. Isotopic measurements were performed by the Functional Ecology Technical Platform (OC 081) at INRA's Forest Ecology and Ecophysiology station (UMR EEF 1137). We thank ATT Company for proofreading of this manuscript. We thank Pascaline Seguy, Cyril Chambon, Valentin Journe and Alexandre Amblard for their help in trait measurements. This research was financed by the French government IDEX-ISITE initiative 16-IDEX-0001 (CAP 20-25).

\section{References}

Aasamaa K, Sõber A, Hartung W, Niinemets Ü (2004) Drought acclimation of two deciduous tree species of different layers in a temperate forest canopy. Trees 18: 93-101
Alía R, Moro J, Denis JB (1997) Performance of Pinus pinaster provenances in Spain: interpretation of the genotype by environment interaction. Can J For Res 27: 1548-1559

Almeida-Rodriguez AM, Cooke JEK, Yeh F, Zwiazek JJ (2010) Functional characterization of drought-responsive aquaporins in Populus balsamifera and Populus simonii x balsamifera clones with different drought resistance strategies. Physiol Plant 140: 321-333

Alpert P, Simms E (2002) The relative advantages of plasticity and fixity in different environments: when is it good for a plant to adjust? Evol Ecol 16: 285-297

Anderegg WRL, Plavcová L, Anderegg LDL (2013) Drought's legacy: multiyear hydraulic deterioration underlies widespread aspen forest die-off and portends increased future risk. Glob Change Biol 19: 1188-1196

Araújo WL, Fernie AR, Nunes-Nesi A (2011) Control of stomatal aperture: a renaissance of the old guard. Plant Signal Behav 6: 1305-1311

Baquedano FJ, Valladares F, Castillo FJ (2008) Phenotypic plasticity blurs ecotypic divergence in the response of Quercus coccifera and Pinus halepensis to water stress. Eur J For Res 127: 495-506

Barchet GLH, Dauwe R, Guy RD, Schroeder, WR, Soolanayakanahally RY, Campbell MM, Mansfield SD (2013) Investigating the drought-stress response of hybrid poplar genotypes by metabolite profiling. Tree Physiol 34: 1203-1219

Barrs HD (1971) Cyclic variations in stomatal aperture, transpiration, and leaf water potential under constant environmental conditions. Annu Rev Plant Physiol 22: 223-236

Battaglia M, Cherry ML, Beadle CL, Sands PJ, Hingston A (1998) Prediction of leaf area index in eucalypt plantations: effects of water stress and temperature. Tree Physiol 18: 521-528

Bazzaz FA (1979) The physiological ecology of plant succession. Annu Rev Ecol Syst 10: 351-371

Beniston M, Stephenson DB, Christensen OB, Ferro CAT, Frei C, Goyette S, Halsnaes K, Holt T, Jylhä K, Koffi B, Palutikof J, Schöll R, Semmler T, Woth K (2007) Future extreme events in European climate: an exploration of regional climate model projections. Clim Change 81: $71-95$

Bizet F, Bogeat-Triboulot M-B, Montpied P, Christophe A, Ningre N, Cohen D, Hummel I (2014) Phenotypic plasticity toward water regime: response of leaf growth and underlying candidate genes in Populus. Physiol Plant 154: 39-53

Bogeat-Triboulot $M-B$, Brosché $M$, Renaut J, Jouve $L$, Le Thiec D, Fayyaz P, Vinocur B, Witters E, Laukens K, Teichmann T, Altman A, Hausman J, Polle A, Kangasjärvi J, Dreyer E (2007) Gradual soil water depletion results in reversible changes of gene expression, protein profiles, ecophysiology, and growth performance in Populus 
euphratica, a poplar growing in arid regions. Plant Physiol 143: 876-892

Bonhomme L, Barbaroux C, Monclus R, Morabito D, Berthelot A, Villar M, Dreyer E, Brignolas F (2008) Genetic variation in productivity, leaf traits and carbon isotope discrimination in hybrid poplars cultivated on contrasting sites. Ann For Sci 65: 503-503

Bradley BA, Early R, Sorte CJB (2015) Space to invade? Comparative range infilling and potential range of invasive and native plants: comparative distributions of natives versus invasives. Glob Ecol Biogeogr 24: 348-359

Bradshaw AD (1965) Evolutionary significance of phenotypic plasticity in plants. Adv Genet 13: 115-155

Bradshaw HD, Ceulemans R, Davis J, Stettler R (2000) Emerging model systems in plant biology: poplar (Populus) as a model forest tree. J Plant Growth Regul 19: 306-313

Bray EA (1997) Plant responses to water deficit. Trends Plant Sci 2: 48-54

Bréda N, Huc R, Granier A, Dreyer E (2006) Temperate forest trees and stands under severe drought: a review of ecophysiological responses, adaptation processes and long-term consequences. Ann For Sci 63: 625-644

Brignolas F, Thierry C, Guerrier G, Boudouresque E (2000) Compared water deficit response of two Populus $x$ euramericana clones, Luisa Avanzo and Dorskamp. Ann For Sci 57: 261-266

Brodribb TJ, Cochard H (2009) Hydraulic failure defines the recovery and point of death in water-stressed conifers. Plant Physiol 149: 575-584

Brodribb TJ, Holbrook NM (2003) Stomatal closure during leaf dehydration, correlation with other leaf physiological traits. Plant Physiol 132: 2166-2173

Burkett VR, Suarez AG, Bindi M, Conde C, Mukerji R, Prather MJ, St. Clair AL, Yohe GW (2014) Point of departure. In: Field CB, Barros VR, Dokken DJ, Mach KJ, Mastrandrea MD, Bilir TE, Chatterjee M, Ebi KL, Estrada YO, Genova RC, Girma B, Kissel ES, Levy AN, MacCracken S, Mastrandrea PR, White LL (eds) Climate Change 2014: Impacts, Adaptation, and Vulnerability. Part A: Global and Sectoral Aspects. Contribution of Working Group II to the Fifth Assessment Report of the Intergovernmental Panel on Climate Change. Cambridge University Press, Cambridge; New York

Cagelli L, Lefèvre F (1995) The conservation of Populus nigra $L$. and gene flow with cultivated poplars in Europe. For Genet 3: 135-144

Cao X, Jia J, Zhang C, Li H, Liu T, Jiang X, Polle A, Peng C, Luo Z (2013) Anatomical, physiological and transcriptional responses of two contrasting poplar genotypes to drought and re-watering. Physiol Plant 151: 480-494

Caruso A, Morabito D, Delmotte F, Kahlem G, Carpin S (2002) Dehydrin induction during drought and osmotic stress in Populus. Plant Physiol Biochem 40: 1033-1042

Ceulemans R, Stettler RF, Hinckley TM, Isebrands JG, Heilman PE (1990) Crown architecture of Populus clones as determined by branch orientation and branch characteristics. Tree Physiol 7: 157-167

Chamaillard S, Fichot R, Vincent-Barbaroux C, Bastien C, Depierreux C, Dreyer E, Villar M, Brignolas F (2011) Variations in bulk leaf carbon isotope discrimination, growth and related leaf traits among three Populus nigra L. populations. Tree Physiol 31: 1076-1087

Chen Y-E, Liu W-J, Su Y-Q, Cui J-M, Zhang Z-W, Yuan M, Zhang H-Y, Yuan S (2016) Different response of photosystem II to short and long-term drought stress in Arabidopsis thaliana. Physiol Plant 158: 225-235

Chevin L-M, Lande R (2009) When do adaptive plasticity and genetic evolution prevent extinction of a density-regulated population? Evolution 64: 1143-1150

Cisneros J, Oki T, Arnell NW, Benito G, Cogley JG, Döll P, Jiang T, Mwakalila SS (2014) Freshwater resources. In: Field CB, Barros VR, Dokken DJ, Mach KJ, Mastrandrea MD, Bilir TE, Chatterjee M, Ebi KL, Estrada YO, Genova RC, Girma B, Kissel ES, Levy AN, MacCracken S, Mastrandrea PR, White LL (eds) Climate Change 2014: Impacts, Adaptation, and Vulnerability. Part A: Global and Sectoral Aspects. Contribution of Working Group II to the Fifth Assessment Report of the Intergovernmental Panel on Climate Change. Cambridge University Press, Cambridge; New York, pp 229-269

Cochard H, Casella E, Mencuccini M (2007) Xylem vulnerability to cavitation varies among poplar and willow clones and correlates with yield. Tree Physiol 27: 1761-1767

Cocozza C, Cherubini P, Regier N, Saurer M, Frey B, Tognetti R (2010) Early effects of water deficit on two parental clones of Populus nigra grown under different environmental conditions. Funct Plant Biol 37: 244

Cohen D, Bogeat-Triboulot M-B, Tisserant E, Balzergue S, Martin-Magniette ML, Lelandais G, Ningre N, Renou JP, Tamby JP, le Thiec D, Hummel I (2010) Comparative transcriptomics of drought responses in Populus: a meta-analysis of genome-wide expression profiling in mature leaves and root apices across two genotypes. BMC Genomics 11: 630

Couso LL, Fernandez RJ (2012) Phenotypic plasticity as an index of drought tolerance in three Patagonian steppe grasses. Ann Bot 110: 849-857

Dalmaris E, Ramalho CE, Poot P, Veneklaas EJ, Byrne M (2015) A climate change context for the decline of a foundation tree species in south-western Australia: insights from phylogeography and species distribution modelling. Ann Bot 116: 941-952

DeWitt TJ, Sih A, Wilson DS (1998) Costs and limits of phenotypic plasticity. Trends Ecol Evol 13: 77-81 
DeWoody J, Trewin H, Taylor G (2015) Genetic and morphological differentiation in Populus nigra L.: isolation by colonization or isolation by adaptation? Mol Ecol 24: 2641-2655

Early R, Sax DF (2014) Climatic niche shifts between species' native and naturalized ranges raise concern for ecological forecasts during invasions and climate change: niche shift during naturalization. Glob Ecol Biogeogr 23: 1356-1365

Fichot R, Barigah TS, Chamaillard S, le Thiec D, Laurans F, Cochard H, Brignolas F (2010) Common trade-offs between xylem resistance to cavitation and other physiological traits do not hold among unrelated Populus deltoides $\times$ Populus nigra hybrids: $x y l e m$ resistance to cavitation and water relations in poplar. Plant Cell Environ 33: 1553-1568

Fichot R, Brignolas F, Cochard H, Ceulemans R (2015) Vulnerability to drought-induced cavitation in poplars: synthesis and future opportunities. Plant Cell Environ 38: 1233-1251

Fu A, Chen Y, Li W (2006) Analysis on water potential of Populus euphratica oliv and its meaning in the lower reaches of Tarim River, Xinjiang. Chin Sci Bull 51: $221-228$

Gebre GM, Kuhns MR, Brandle JR (1994) Organic solute accumulation and dehydration tolerance in 3 water stressed Populus deltoides clones. Tree Physiol 14: 575-587

Ghalambor CK, McKay JK, Carroll SP, Reznick DN (2007) Adaptive versus non-adaptive phenotypic plasticity and the potential for contemporary adaptation in new environments. Funct Ecol 21: 394-407

Ghalambor CK, Hoke KL, Ruell EW, Fischer EK, Reznick DN, Hughes KA (2015) Non-adaptive plasticity potentiates rapid adaptive evolution of gene expression in nature. Nature 525: 372-375

Giovannelli A, Deslauriers A, Fragnelli G, Scaletti L, Castro G, Rossi S, Crivellaro A (2007) Evaluation of drought response of two poplar clones (Populus x canadensis Monch "I-214" and P. deltoides marsh. "Dvina") through high resolution analysis of stem growth. J Exp Bot 58: 2673-2683

Guet J, Fichot R, Lédée C, Laurans F, Cochard H, Delzon S, Bastien C, Brignolas F (2015) Stem xylem resistance to cavitation is related to xylem structure but not to growth and water-use efficiency at the within-population level in Populus nigra L. J Exp Bot 66: 4643-4652

Hallé F, Oldeman RAA, Tomlinson PB (1978) Tropical Trees and Forests. Springer, Berlin, Heidelberg

Hamanishi ET, Raj S, Wilkins O, Thomas BR, Mansfield S, Plant AL, Campbell M (2010) Intraspecific variation in the Populus balsamifera drought transcriptome: within-species variation in Populus transcriptome. Plant Cell Environ 33: 1742-1755
Hamanishi ET, Thomas BR, Campbell MM (2012) Drought induces alterations in the stomatal development program in Populus. J Exp Bot 63: 4959-4971

Hamanishi ET, Barchet GL, Dauwe R, Mansfield S, Campbell M (2015) Poplar trees reconfigure the transcriptome and metabolome in response to drought in a genotype- and time-of-day-dependent manner. BMC Genomics 16: 329

Hanin M, Brini F, Ebel C, Toda Y, Takeda S, Masmoudi K (2011) Plant dehydrins and stress tolerance. Plant Signal Behav 6: 1503-1509

Hargreaves AL, Samis KE, Eckert CG (2014) Are species' range limits simply niche limits writ large? A review of transplant experiments beyond the range. Am Nat 183: 157-173

Henry HAL, Aarssen LW (1997) On the relationship between shade tolerance and shade avoidance strategies in woodland plants. Oikos 80: 575

logna PA, Bucci SJ, Scholz FG, Goldstein G (2013) Homeostasis in leaf water potentials on leeward and windward sides of desert shrub crowns: water loss control vs. high hydraulic efficiency. Oecologia 173: 675-687

Isebrands JG, Richardson J (2014) Poplar and Willow - Trees for Society and the Environment. The Food and Agriculture Organization of the United Nations and CABI, Roma, Boston

Jajic I, Sarna T, Strzalka K (2015) Senescence, stress, and reactive oxygen species. Plants 4: 393-411

Kawecki TJ, Ebert D (2004) Conceptual issues in local adaptation. Ecol Lett 7: 1225-1241

Lambers H, Chapin FS, Pons TL (2008) Plant Physiological Ecology. Springer, New York

Lambs L, Loubiat M, Girel J, Tissier J, Peltier JP, Marigo G (2006) Survival and acclimation of Populus nigra to drier conditions after damming of an alpine river, southeast France. Ann For Sci 63: 377-385

Lamy J-B, Delzon S, Bouche PS, Alia R, Vendramin GG, Cochard H, Plomion C (2014) Limited genetic variability and phenotypic plasticity detected for cavitation resistance in a Mediterranean pine. New Phytol 201: $874-886$

Le S, Josse J, Husson F (2008) FactoMineR: an R package for multivariate analysis. J Stat Softw 25: 1-18

Lebart L, Morineau A, Piron M (1995) Statistique Exploratoire Multidimensionnelle, 1st Edn. Dunod, Paris

Marron N, Delay D, Petit J-M, Dreyer E, Kahlem G, Delmotte FM, Brignolas F (2002) Physiological traits of two Populus x euramericana clones, Luisa Avanzo and Dorskamp, during a water stress and re-watering cycle. Tree Physiol 22: 849-858

Marron N, Dreyer E, Boudouresque E, Delay D, Petit JM, Delmotte FM, Brignolas F (2003) Impact of successive drought and re-watering cycles on growth and specific leaf area of two Populus x canadensis (Moench) clones, 
"Dorskamp" and "Luisa_Avanzo". Tree Physiol 23: 1225-1235

Martorell S, Medrano H, Tomàs M, Escalona JM, Flexas J, Diaz-Espejo A (2014) Plasticity of vulnerability to leaf hydraulic dysfunction during acclimation to drought in grapevines: an osmotic-mediated process. Physiol Plant 153: $381-391$

McCully ME (1999) Root xylem embolisms and refilling. Relation to water potentials of soil, roots, and leaves, and osmotic potentials of root xylem sap. Plant Physiol 119: $1001-1008$

McDowell N, Pockman WT, Allen CD, Breshears DD, Cobb N, Kolb T, Plaut J, Sperry J, West A, Williams DG, Yepez EA (2008) Mechanisms of plant survival and mortality during drought: why do some plants survive while others succumb to drought? New Phytol 178: 719-739

McKown AD, Guy RD, Klápště J, Geraldes A, Friedmann M, Cronk QCB, el-Kassaby YA, Mansfield SD, Douglas CJ (2014) Geographical and environmental gradients shape phenotypic trait variation and genetic structure in Populus trichocarpa. New Phytol 201: 1263-1276

Milburn JA (1966) The conduction of sap: I. Water conduction and cavitation in water stressed leaves. Planta 69: 34-42

Monclus R, Dreyer E, Villar M, Delmotte FM, Delay D, Petit JM, Barbaroux C, le Thiec D, Brechet C, Brignolas F (2006) Impact of drought on productivity and water use efficiency in 29 genotypes of Populus deltoides $\mathrm{x}$ Populus nigra. New Phytol 169: 765-777

Morabito D, Caruso A, Carpin S, Carli C, Laurans F, Depierreux C, Kahlem G, Label P (2006) Cambial activity of Populus tremula $\times$ Populus alba clone 717-1B4 in hydroponic culture. Can J For Res 36: $719-724$

Moran NA (1992) The evolutionary maintenance of alternative phenotypes. Am Nat 139: 971-989

Nardini A, Tyree MT, Salleo S (2001) Xylem cavitation in the leaf of Prunus laurocerasus and its impact on leaf hydraulics. Plant Physiol 125: 1700-1709

Nicotra AB, Atkin OK, Bonser SP, Davidson AM, Finnegan EJ, Mathesius $U$, Poot $P$, Purugganan MD, Richards $C L$, Valladares F, Van Kleunen M (2010) Plant phenotypic plasticity in a changing climate. Trends Plant Sci 15: 684-692

Parker J (1956) Drought resistance in woody plants. Bot Rev 22: 241-289

Parmesan C, Hanley ME (2015) Plants and climate change: complexities and surprises. Ann Bot 116: 849-864

Passioura JB (2002) Soil conditions and plant growth. Plant Cell Environ 25: 311-318

Pedrol N, Ramos P, Reigosa MJ (2000) Phenotypic plasticity and acclimation to water deficits in velvet-grass: a long-term greenhouse experiment. Changes in leaf morphology, photosynthesis and stress-induced metabolites. J Plant Physiol 157:

383-393

Pelah D, Wang W, Altman A, Shoseyov O, Bartels D

(1997) Differential accumulation of water stress-related proteins, sucrose synthase and soluble sugars in Populus species that differ in their water stress response. Physiol Plant 99: 153-159

Rameau J-C, Mansion D, Dumé G (1989) Flore forestière française: guide écologique illustré. Institut pour le développement forestier, Ministère de l'agriculture et de la forêt, Direction de l'espace rural et de la forêt, Ecole nationale du génie rural, des eaux et des forêts, Paris

Reed TE, Waples RS, Schindler DE, Hard JJ, Kinnison MT (2010) Phenotypic plasticity and population viability: the importance of environmental predictability. Proc R Soc B 277: 3391 -3400

Regier N, Streb S, Cocozza C, Schaub M, Cherubini P, Zeeman S, Frey B (2009) Drought tolerance of two black poplar (Populus nigra L.) clones: contribution of carbohydrates and oxidative stress defence. Plant Cell Environ 32: 1724-1736

Sack L, Holbrook NM (2006) Leaf hydraulics. Annu Rev Plant Biol 57: 361-381

Sala A, Piper F, Hoch G (2010) Physiological mechanisms of drought-induced tree mortality are far from being resolved: letters. New Phytol 186: 274-281

Sax D, Stachowicz J, Brown J, Bruno J, Dawson M, Gaines S, Grosberg R, Hastings A, Holt R, Mayfield M (2007) Ecological and evolutionary insights from species invasions. Trends Ecol Evol 22: 465-471

Schneider CA, Rasband WS, Eliceiri KW (2012) NIH image to ImageJ: 25 years of image analysis. Nat Methods 9: 671-675

Sellin A (1999) Does pre-dawn water potential reflect conditions of equilibrium in plant and soil water status? Acta Oecol 20: 51-59

Sevanto S, Mcdowell NG, Dickman LT, Pangle R, Pockman W (2014) How do trees die? A test of the hydraulic failure and carbon starvation hypotheses: how do trees die? Plant Cell Environ 37: 153-161

Shackel KA, Lampinen B, Ahmadi H, Biasi W, Buchner R, Goldhamer D, Gurusinghe S, Hasey J, Kester D, Krueger B (1997) Plant water status as an index of irrigation need in deciduous fruit trees. HortTechnology 7: 23-28

Stalfelt MG (1955) The stomata as a hydrophotic regulator of the water deficit of the plant. Physiol Plant 8: 572-593

Steinger T, Roy BA, Stanton ML (2003) Evolution in stressful environments. II. Adaptive value and costs of plasticity in response to low light in Sinapis arvensis. J Evol Biol 16: 313-323

Sultan SE (2000) Phenotypic plasticity for plant development, function and life history. Trends Plant Sci 5: 537-542 
Tardieu F, Simonneau T (1998) Variability among species of stomatal control under fluctuating soil water status and evaporative demand: modelling isohydric and anisohydric behaviours. J Exp Bot 49: 419-432

Taylor G (2002) Populus: Arabidopsis for forestry. Do we need a model tree? Ann Bot 90: 681-689

Thomas DS, Eamus D (1999) The influence of predawn leaf water potential on stomatal responses to atmospheric water content at constant $\mathrm{Ci}$ and on stem hydraulic conductance and foliar ABA concentrations. J Exp Bot 50: 243-251

Tyree MT, Sperry JS (1988) Do woody plants operate near the point of catastrophic xylem dysfunction caused by dynamic water stress? Answers from a model. Plant Physiol 88: 574-580

Valladares F, Niinemets Ü (2008) Shade tolerance, a key plant feature of complex nature and consequences. Annu Rev Ecol Evol Syst 39: 237-257

Valladares F, Martinez-Ferri E, Balaguer L, Perez-Corona E, Manrique E (2000) Low leaf-level response to light and nutrients in Mediterranean evergreen oaks: a conservative resource-use strategy?: RESEARCH plastic leaf response to light and nutrients in two oaks. New Phytol 148: 79-91

Valladares F, Arrieta S, Aranda I, Lorenzo D, Sanchez-Gomez D, Tena D, Suarez F, Pardos JA (2005) Shade tolerance, photoinhibition sensitivity and phenotypic plasticity of Ilex Aquifolium in continental Mediterranean sites. Tree Physiol 25: 1041-1052

Valladares F, Sanchez-Gomez D, Zavala MA (2006) Quantitative estimation of phenotypic plasticity: bridging the gap between the evolutionary concept and its ecological applications. J Ecol 94: 1103-1116

Valladares F, Gianoli E, Gómez JM (2007) Ecological limits to plant phenotypic plasticity. New Phytol 176: 749-763

Van Kleunen M, Fischer M (2005) Constraints on the evolution of adaptive phenotypic plasticity in plants: research review. New Phytol 166: 49-60 van Mantgem PJ, Stephenson NL, Byrne JC, Daniels LD, Franklin JF, Fule PZ, Harmon ME, Larson AJ, Smith JM,
Taylor AH, Veblen TT (2009) Widespread increase of tree mortality rates in the western United States. Science 323: $521-524$

Viger M, Smith HK, Cohen D, Dewoody J, Trewin H, Steenackers M, Bastien C, Taylor G (2016) Adaptive mechanisms and genomic plasticity for drought tolerance identified in European black poplar (Populus nigra L.) Tree Physiol 0: 1-20

Villar M, Forestier O (2009) Le Peuplier noir en France: pourquoi conserver ses ressources génétiques et comment les valoriser? Rev For Fr LXI-5: 457-466

Willis CG, Ruhfel B, Primack RB, Miller-Rushing AJ, Davis CC (2008) Phylogenetic patterns of species loss in Thoreau's woods are driven by climate change. Proc Natl Acad Sci USA 105: 17029-17033

Wu R, Hinckley TM (2001) Phenotypic plasticity of sylleptic branching: genetic design of tree architecture. Crit Rev Plant Sci 20: 467-485

\section{Supporting Information}

Additional Supporting Information may be found in the online version of this article:

Table S1. Branch growth traits of 14 well-watered (WW) and droughted (WS) black poplar genotypes subjected to 8-day water deficit.

Table S2. Principal component analysis loadings of the six RDPI traits.

Table S3. Test of genotype effect on plasticity degree using RDPI estimated on physiological and growth traits of 14 black poplar genotypes at the maximal water deficit (day 8).

Fig. S1. Mean percentage evolution of weight loss of 14 black poplars growing in pots subjected to progressive 8-day water deficit.

Fig. S2. Mean ( \pm SE) Specific Leaf Area of 14 well-watered (gray bars) and droughted (white bars) black poplar genotypes at the maximal water deficit (day 8). 